\title{
Composition, distribution and supposed origin of mineral inclusions in sessile oak wood - consequences for microdensitometrical analysis
}

\author{
Dries VAnsteenkiste ${ }^{\mathrm{a} *}$, Joris VAN ACKeR ${ }^{\mathrm{a}}$, Marc SteVens $^{\mathrm{a}}$, Didier Le ThIEc ${ }^{\mathrm{b}}$, Gérard NePVeU $^{\mathrm{c}}$ \\ ${ }^{a}$ Ghent University, Faculty of Bioscience Engineering, Dept. Forest and Water Management, Section Wood Biology and Wood Technology, \\ Coupure Links 653, 9000 GENT, Belgium \\ b INRA Nancy, UMR Écologie et Écophysiologie Forestières INRA-UHP Nancy I 1137, Équipe Bioclimatologie, 54280 Champenoux, France \\ ${ }^{\mathrm{c}}$ INRA Nancy, Laboratoire d'Étude des Ressources Forêt-Bois, UMR INRA-ENGREF 1092, Équipe de Recherches sur la Qualité des Bois, \\ 54280 Champenoux, France
}

(Received 14 December 2005; accepted 8 September 2006)

\begin{abstract}
SEM and light-microscopical observations, supported by chemical microanalysis with an EDXA system, revealed that light-saturated pixels observed in X-ray negatives of sessile oak (Quercus petraea Liebl.) wood were caused by inorganic deposits present inside multiseriate ray and axial parenchyma cells. Calcium oxalate crystals, silica grains and amorphous granules with varied mineral compositions have been identified. The wood strips of three out of six sampled trees contained measurable amounts of mineral inclusions which were quantified using image analysis. Based on the variations of mineral content observed between trees and within and between annual rings of the same tree, some hypotheses were formulated concerning the factors involved in the formation of inorganic deposits in oak wood. Their occurrence varies depending on the mineral concerned and seems to be controlled largely by a tree effect. The time of formation appears to coincide with a shifting of the oak wood's functions as a result of heartwood formation processes (inter-annual scale) or changes in leaf phenology and climate (intra-annual scale). In addition, the technical consequences of their presence as well as their effects on wood density measurements through microdensitometry are discussed.
\end{abstract}

Quercus / mineral deposits / microdensitometry / image analysis / dendro-ecology

Résumé - Composition, distribution et origine supposée d'inclusions minérales dans le bois de chêne sessile - conséquences pour l'analyse microdensitométrique. Des observations à l'aide de microscopes électronique à balayage et optique, appuyées par des analyses élémentaires au moyen d'un système EDXA, ont révélé que les points-images saturés en niveau de gris, constatés dans les négatifs de radiographies de bois de chêne sessile (Quercus petraea Liebl.), étaient dus à des dépôts inorganiques présents à l'intérieur des cellules parenchymateuses des rayons ligneux multisériés et du parenchyme axial. Des cristaux d'oxalate de calcium, des grains de silice et des granules amorphes ayant des compositions minérales variées ont été identifiés. Des barrettes de trois sur six arbres échantillonnés contenaient des quantités mesurables d'inclusions minérales qui ont été quantifiées par analyse d'images. En se basant sur les variations du contenu en dépôts minéraux observées entre arbres ainsi qu'à l'intérieur d'un arbre, aux niveaux intra- et intercerne, quelques hypothèses ont été avancées concernant les facteurs potentiellement responsables de la formation de dépôts minéraux chez le chêne. Leur présence dépend du minéral concerné et semble être contrôlée par un fort effet arbre. L'apparition des minéraux coïncide apparemment avec des changements de fonctions du bois relatifs aux processus de duraminisation (échelle interannuelle) ou correspondant à des évolutions phénologiques ou climatiques (échelle intra-annuelle). Enfin, les conséquences techniques ainsi que les effets de leur présence sur des mesures de la densité du bois par analyse microdensitométrique sont discutés.

Quercus / dépôts minéraux / microdensitométrie / analyse d'images / dendroécologie

\section{INTRODUCTION}

Following the pioneering work of Polge [19,20], microdensitometrical analysis of X-ray photographs of wood became a valuable technique used in dendro-ecological and technological research. The 2-D grey-level maps created with conventional radiographical procedures have been used recently to identify different woody tissues in oak species and to quantify their proportions and density variations through statistical and/or image analysis techniques $[6,25]$. The grey-level of an image point in an X-ray photo of wood offers a reliable measure of wood density because it is proportional to the at-

\footnotetext{
*Corresponding author: Dries.Vansteenkiste@UGent.be
}

tenuation of soft (i.e. long-wavelength) X-ray photons by its low atomic number constituents, being carbon, hydrogen and oxygen $[3,19,20]$. This paper addresses a subject that was first considered to be an anomaly encountered in the image analysis of X-ray negatives of thin cross-sections of sessile oak wood (Quercus petraea Liebl.). In some scanned negatives, (nearly) light-saturated pixels - either scattered or aggregated - were observed. These were supposed to be due to random, systematic effects that occurred during film development and/or subsequent scanning. However, closer visual examination and repeated scanning of such negatives showed that the whitish objects were not randomly distributed but concentrated rather in specific areas (as illustrated in Fig. 1). This indicated that substances with densities well above that of ligneous cell walls 


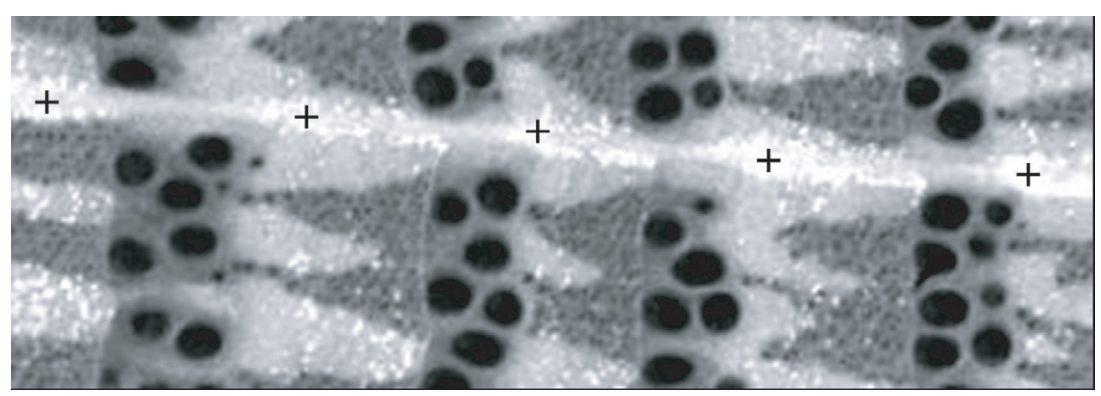

Figure 1. X-ray image of a short ring-sequence showing scattered and aggregated (+) pixels with (nearly) saturated grey-levels. Image size is $7.41 \mathrm{~mm} \times 2.54 \mathrm{~mm}$; scene extracted from a pith-to-bark strip of $0.7 \mathrm{~mm}$ thick.

- $1.53 \mathrm{~g} / \mathrm{cm}^{3}$ according to Hägglund [7] - were present inside or on the surface of the irradiated samples. Initially, the highdensity substances were thought to be inorganic contaminations introduced during sample preparation. However, lightsaturated pixels could not be observed in all X-ray negatives, in spite of an identical sample preparation. Therefore, the substances more likely had an endogenous origin. It is widely known that oxides, oxalates, carbonates and phosphates of calcium or silicium, sometimes accompanied by other organic acids, may be deposited in secondary xylem vessels, tracheids or parenchyma cells of trees $[4,8]$. The coverage in literature of the effects of mineral inclusions in wood on microdensitometrical analyses has been scanty though. In the 1970's, Janin and Clément [10] observed mineral streaks within xylem vessels of Populus spp. using X-ray photographs. They stated that the strong attenuation of X-rays in poplar wood caused by mineral inclusions had not been reported previously. Using gravimetrical techniques, Nepveu et al. [17] demonstrated a significant influence of the presence of calcium carbonate crystals $\left(\mathrm{CaCO}_{3}\right.$, calcite) on the infradensity of poplar wood.

The aims of the present study were to verify the crystalline nature of the high-density substances, to make assessments about their chemical composition, abundance and distribution, and to evaluate the implications of their presence for microdensitometrical analyses of sessile oak wood. Although these "contaminations" were obstructing the image analysis of Xray photographs, the quantitative information obtained in this investigation turned out to be potentially valuable for dendroecological and wood technological research. Therefore, the purpose of this paper is also to show the significance of quantitative data on mineral deposits in wood. Some assumptions concerning the possible cause(s) of mineral deposits are put forward.

\section{MATERIALS AND METHODS}

The outer 60 rings at breast-height of six mature sessile oaks from five different forests in NE France have been investigated: two from Bezange in Lorraine (trees I and II) and four respectively from Hagenau, Nonnenhardt, Saverne and Steinbach in Alsace (trees III to VI). At the time of felling in winter 1992-1993, tree ages at breast-height ranged from 143 to 207 years. From each tree, a pair of matching pith-to-bark strips consisting of a $0.7 \mathrm{~mm}$ and a $2 \mathrm{~mm}$ thick strip was sawn out along a radius perpendicular to the longest diagonal. This yielded 12 strips of about $15 \mathrm{~mm}$ wide tangentially.

The radiographical procedures were adapted from those proposed by Polge [19,20]. Samples were placed on fine-grained radiographic film (Kodak) and irradiated by an X-ray source positioned at $2.5 \mathrm{~m}$ height. Respectively for the $0.7 \mathrm{~mm}$ and the $2 \mathrm{~mm}$ strips, the following settings were used: intensities of 12 and $10 \mathrm{~mA}$; accelerating tensions of 7.5 and $10 \mathrm{kV}$; exposures of 4 and $2 \mathrm{~h}$. The X-ray negatives were digitized with a scanner at 8 bits and 1200 dpi resolutions, which corresponds to 256 grey-levels and square pixels of $21.2 \mu \mathrm{m}$.

The scanned negatives of the 12 strips were fed as input to a semiautomated image analysis script programmed in the C-like Object Oriented Language of Visilog 5.4 software (Noesis, France). This script has been developed specifically for the analysis of X-ray images of ring-porous oak wood [25]. It allows delimiting annual rings and earlywood/latewood zones and identifying four anatomical units in each ring, macro-porous vessels $(\mathrm{V})$, vasicentric tracheid areas $(\mathrm{T})$, libriform fiber fields $(\mathrm{F})$ and multiseriate rays (R), as shown in Figure 2. The pixels of saturated grey-level are considered as an additional unit and are referred to as crystals (C) or C-pixels. With the grey-level input image and the 2-D anatomical map this device produces, the relative surface proportion and the densitometrical properties - in terms of grey-level or calibrated density values - of each anatomical unit can be quantified for each ring. Furthermore, radial profiles can be calculated which describe the intra-ring variations of tissue proportions and microdensity features. Compared to classical microdensitometry, this new methodology gives access to high-resolution anatomical and densitometrical information of each anatomical element, both in 1-D and 2-D. Due to technical limitations, the conversion of grey-level to real density values was possible only for the $2 \mathrm{~mm}$ strips; for reasons explained in the discussion part of this paper, densitometrical results will not be presented in detail.

Based on the position of (nearly) light-saturated pixels in the Xray negatives, small areas were located in the corresponding wood strips where high-density substances were expected to be found in high concentrations. Such pixels were observed in the images of all strips belonging to three trees (I, II and IV). The scans of tree I displayed substantial amounts of light-saturated pixels in all 60 growthrings. By means of a scalpel, tiny specimens of several $\mathrm{mm}^{3}$ were cut out from this tree's strips, in the vicinity of the sapwood-heartwood boundary and including multiseriate ray tissue. These samples were covered with carbon by evaporation of graphite under vacuum, prior to visual exploration at $654 \times$ magnification with a Scanning Electron Microscope (SEM - Cambridge Stereoscan 90) and chemical characterization with Energy Dispersive X-ray Analysis (EDXA at $15 \mathrm{kV}$ ). The EDXA system calculated the concentration of the atomic 


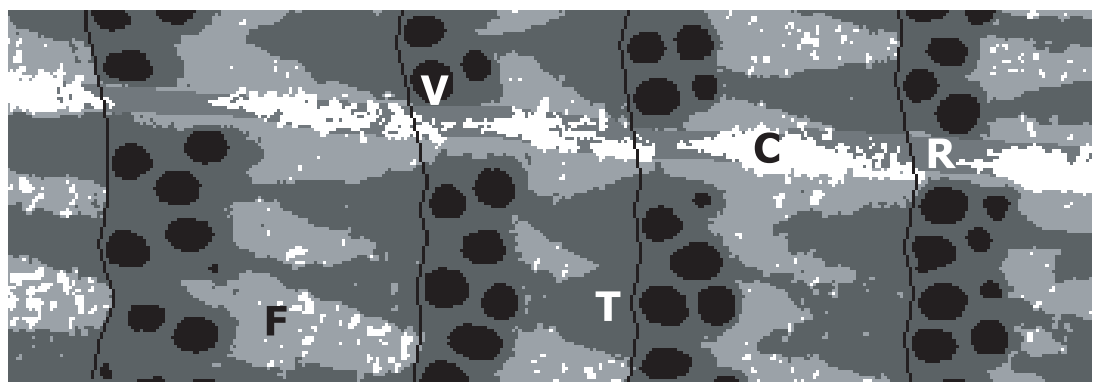

Figure 2. Labelled output image produced by automated segmentation of the X-ray image shown in Figure 1: macro-porous earlywood vessels (V, black), vasicentric tracheid areas ( $\mathrm{T}$, darkest grey), libriform fibre fields (F, light grey) and multiseriate rays (R, dark grey). The lightsaturated pixels are considered as an additional anatomical unit and labelled as crystals (C, white). Black lines represent growth-ring borders identified by automated image processing.

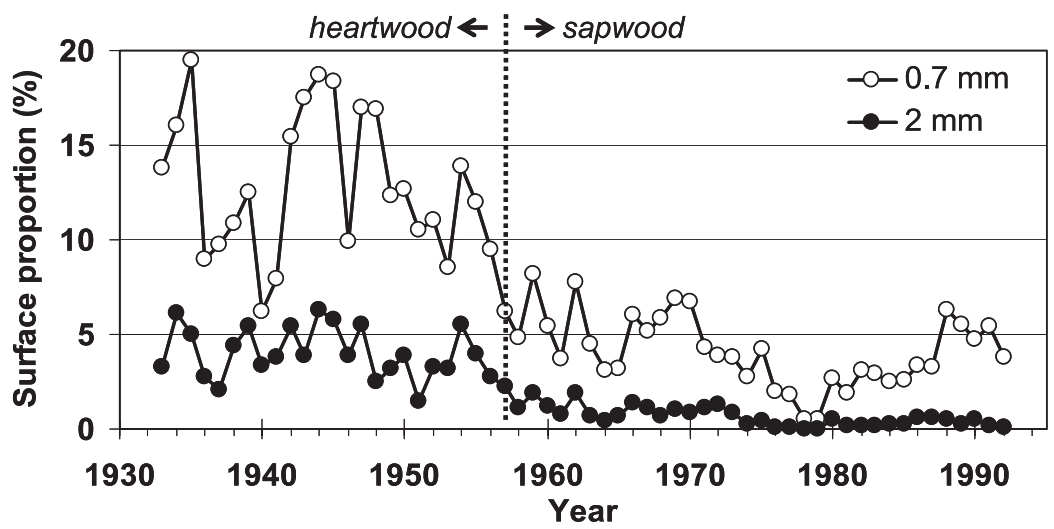

Figure 3. Radial evolution of the relative intra-ring proportion (in \%) of (nearly) light-saturated pixels in the outer 60 rings of tree I - values estimated using two matching strips of 0.7 and $2 \mathrm{~mm}$ thickness. The vertical dotted line marks the sapwood-heartwood transition (around ring 36, year 1957).

elements $\mathrm{Na}, \mathrm{Mg}, \mathrm{Al}, \mathrm{Si}, \mathrm{P}, \mathrm{S}, \mathrm{Cl}, \mathrm{K}, \mathrm{Ca}$ and $\mathrm{Fe}$ in submicroscopic areas or objects of interest, expressed as weight percentages, i.e. in $\mathrm{g}$ per $100 \mathrm{~g}$ of dry material. Using the internet database Webmineral, an attempt was made to identify the objects based on their chemical composition.

In addition, several $15 \mu \mathrm{m}$-thick cross-sections, double-stained with safranin and astra-blue, were prepared from the same tree, which partially matched the X-rayed strips. The sections were screened for crystalliferous cells with an Olympus VANOX-S light microscope. Crystals are easily overlooked in thin cross-sections viewed under the light-microscope. However, the use of different contrast enhancing techniques, such as polarization, darkfield illumination (DF), fluorescence (FL) or Nomarski differential interference contrast (NDIC) may highlight crystals against lumina or cell walls and help locating them in specific cell types.

\section{RESULTS}

\subsection{Quantification of mineral inclusions through image analysis of X-ray negatives}

Substantial amounts of (nearly) light-saturated pixels - labelled C-pixels in Figure 2 - were identified in all 60 rings of trees I and II. Smaller proportions were found in tree IV. In the strips of the remaining Alsacian trees (III, V and VI), no such
Table I. Number of rings $(N)$ with (nearly) light-saturated pixels and minimum, maximum and average surface proportion (in \%) of such pixels in the X-rays of $0.7 \mathrm{~mm}$ and $2 \mathrm{~mm}$ strips of trees I, II and IV (60 rings analysed per strip).

\begin{tabular}{lcccccccc}
\hline & \multicolumn{4}{c}{$0.7 \mathrm{~mm}$} & \multicolumn{4}{c}{$2 \mathrm{~mm}$} \\
\cline { 2 - 9 } Tree & Min & Max & Mean & $N$ & Min & Max & Mean & $N$ \\
\hline I & 0.5 & 19.5 & 7.7 & 60 & 0.0 & 6.3 & 2.0 & 58 \\
II & 0.4 & 7.7 & 3.8 & 60 & 0.0 & 7.1 & 2.3 & 57 \\
IV & 0.0 & 2.2 & 0.3 & 55 & 0.0 & 2.4 & 0.4 & 37 \\
\hline
\end{tabular}

pixels were detected. The number of rings containing C-pixels as well as the minimum, maximum and average surface proportion (in \%) of C-pixels calculated for the trees I, II and IV are listed in Table I, both for the $0.7 \mathrm{~mm}$ and the $2 \mathrm{~mm}$ strips.

Especially in tree I, but also in tree II, consistently higher amounts of C-pixels were detected in the rings of the $0.7 \mathrm{~mm}$ strip than in those of the $2 \mathrm{~mm}$ strip. This difference is apparent also in the profiles showing the radial evolution of the relative proportion of C-pixels in the outer 60 rings of tree I (Fig. 3). It becomes smaller, however, when the amount of C-pixels is lower, as in trees II and IV. Fewer rings with Cpixels are detected then, especially in $2 \mathrm{~mm}$ strips compared 


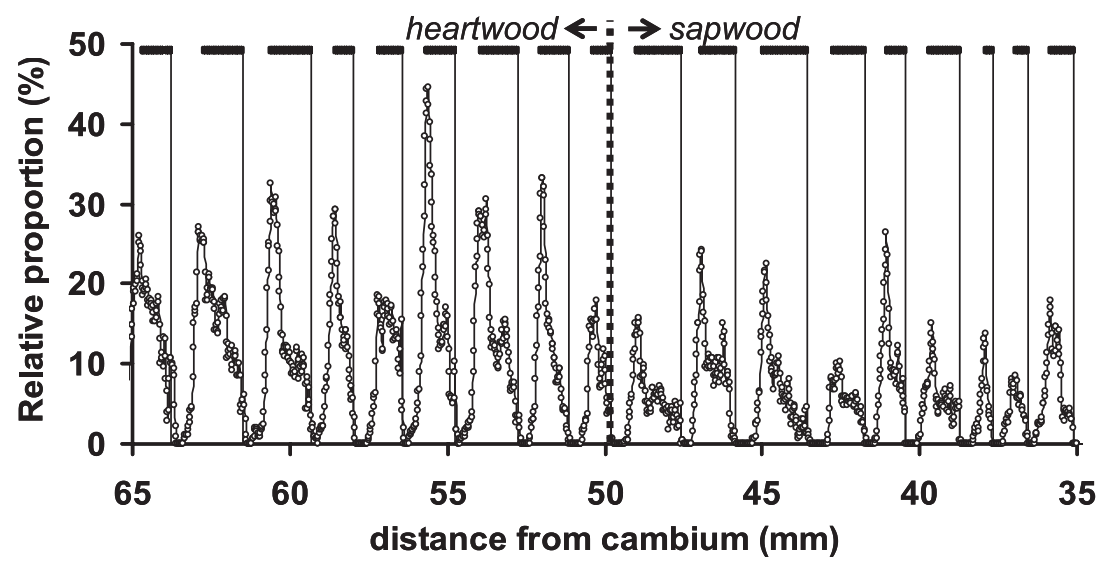

Figure 4. Radial intra-ring distribution of the relative proportion (in \%) of (nearly) light-saturated pixels in the sapwood-heartwood transition zone of tree I, i.e. around ring 36 (marked with dotted line). Vertical lines indicate ring limits; black horizontal dashes show the extent of the latewood in each ring.

to $0.7 \mathrm{~mm}$ strips (e.g. 37 versus 55 rings in tree IV, Tab. I). The discrepancies found between strips of $0.7 \mathrm{~mm}$ and $2 \mathrm{~mm}$ thickness can be explained principally by the different irradiation parameters (duration, intensity and accelerating tension) that have been used: the $2 \mathrm{~mm}$ strips had been exposed to X-rays for only two hours, while the $0.7 \mathrm{~mm}$ strips were irradiated for four hours, and the physical properties of the X-rays differed.

The proportion of C-pixels varies from year to year (Figs. 3 and 4). Moreover, in the direction of cambium to pith, a marked increase of the proportion of C-pixels is noted near the sapwood-heartwood boundary (in tree I at $50 \mathrm{~mm}$ from the cambium, around ring 36, i.e. year 1957 - Fig. 3). This increase was evident also in the radial profiles of tree II (at $25 \mathrm{~mm}$ from the cambium around ring 22, i.e. year 1971), but not in those of tree IV which contained very few C-pixels. Both in trees I and II, it was more marked in the $0.7 \mathrm{~mm}$ than in the $2 \mathrm{~mm}$ strip. Overall, the ring-to-ring variations are more distinct in thinner strips and when the proportion of C-pixels is higher.

The radial intraring distribution of C-pixels (in \%) in the sapwood-heartwood transition zone of tree I is shown in detail for the $0.7 \mathrm{~mm}$ strip in Figure 4. Based on the position of the growth-ring borders and the extent of the latewood flags, it is clear that the majority of C-pixels is located in the latewood zone (see also Figs.1 and 2). In most of the rings, a steep concentration increase is observed at the earlywood-latewood transition, reaching a maximum at the beginning of the latewood which may mount up to $45 \%$ of the tangential stretch considered. Hereafter, the proportion of C-pixels gradually diminishes towards the end of the growth ring.

\subsection{Identification of crystals through SEM observations and chemical analysis with EDXA}

For reference, chemical analysis was performed first on pure ligneous material by selecting an area in a small sample that was visually free of inorganic particles (at $654 \times$ magnification). These reference values (EDXA 1) were compared to literature data collected by Hägglund [7] and Meerts [15] for pedunculate oak ( $Q$. robur L.) and sessile oak heartwood and sapwood ashes, as listed in Table II. The concentrations estimated by EDXA 1 are overall higher but reasonably close to these reference values, especially those of sapwood. Subsequently, some of the intact or fragmented crystal-like particles observed on the surface of the small samples (Fig. 5) were subjected to area- or spot-size EDXA (Tab. II).

EDXA 2 assessed the chemical composition of the area shown in Figure 5A which contains three distinct crystalloid fragments and lots of dispersed debris. Compared to EDXA 1 and literature data, all monitored elements were found to be present in increased concentrations. Particularly high concentrations were recorded for calcium (4.05\%), sulphur $(3.54 \%)$ and silicium $(3.25 \%)$ and, to a minor extent, for potassium $(0.99 \%)$, aluminium $(0.88 \%)$, iron $(0.65 \%)$ and magnesium $(0.60 \%)$.

The spot-size analyses of one of three similar crystalloid fragments ("3" in Fig. 5A), an amorphous granule (pointed at with a white arrow in Fig. 5A) and of the intact crystal discovered inside a ray cell ("4" in Fig. 5B) yielded the results listed respectively under EDXA 3, 4 and 5 in Table II. About $50 \%$ of fragment " 3 " is made up of silicium (EDXA 3); compared to EDXA 1, the complete absence of aluminium, chlorine, potassium and calcium is noteworthy. The amorphous granule (EDXA 4) contains over $66 \%$ iron and smaller concentrations of sulphur $(0.65 \%)$, calcium $(0.59 \%)$ and silicium $(0.57 \%)$. The main mineral constituent of the crystal found inside a ray cell was calcium $(21.61 \%)$; the concentrations of other elements were insignificant (EDXA 5).

\subsection{Localisation of crystals in thin cross-sections by means of light microscopy}

Prismatic crystals - mostly isodiametric or slightly elongated - have been found in axial parenchyma cells (Figs. 6A and $6 \mathrm{~B})$, in cells inside or adjacent to multiseriate rays (Figs. 6B and 6C) and in short (Fig. 6C) or long (Fig. 6D) 


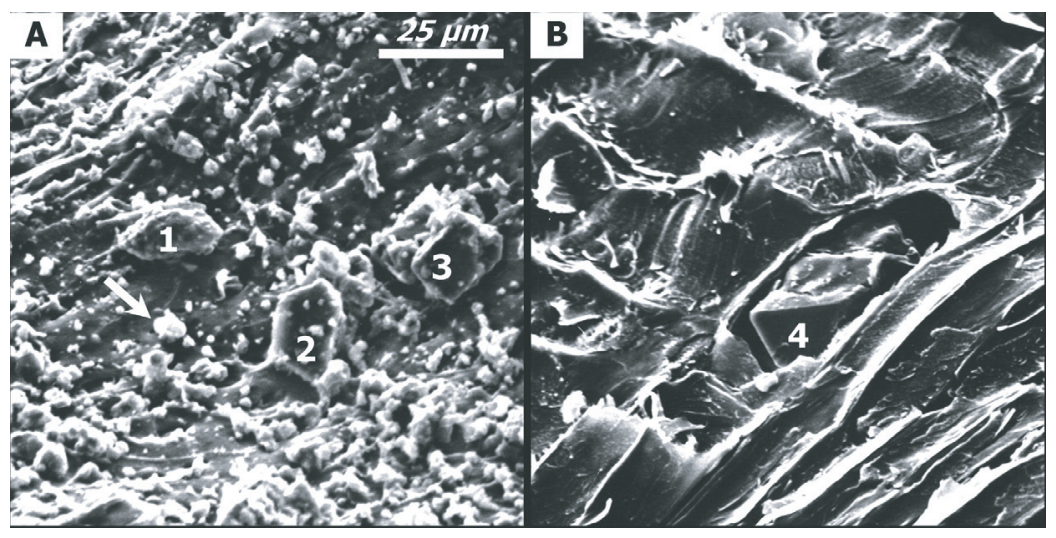

Figure 5. Scanning electron microscopical observations made on small samples at $654 \times$ magnification: (A) three fragmented crystalloid particles (labels 1 to 3) and amorphous granules (e.g. white arrow) surrounded by debris, on the sample surface; (B) free, fairly intact, large crystal found lodged inside a parenchyma ray cell that had been cut open during sample preparation (label 4). The $25 \mu \mathrm{m}$ scale bar is valid for both SEM photographs.

Table II. Elementary composition of Pedunculate (1 = Hägglund 1951, 2 = Meerts 2002) and Sessile (3 = Meerts 2002) oak sapwood and heartwood and results of five SEM-EDXA analyses performed on small Sessile oak wood samples. All values expressed in $\mathrm{g}$ per $100 \mathrm{~g}$ of dry material. Numbers in boldface indicate higher values. EDXA 1: reference analysis in a clear submicroscopic area, i.e. on pure ligneous material; EDXA 2: field-size analysis of the scene shown in Figure 5A. Specific spot-size analyses have been performed on the crystalloid fragment ("3" in Fig. 5A - EDXA 3), on the amorphous granule (under white arrow in Fig. 5A - EDXA 4) and on the crystal inside a ray cell labelled "4" in Figure 5B (EDXA 5).

\begin{tabular}{lcccccccccc}
\hline Element & $\mathrm{Na}$ & $\mathrm{Mg}$ & $\mathrm{Al}$ & $\mathrm{Si}$ & $\mathrm{P}$ & $\mathrm{S}$ & $\mathrm{Cl}$ & $\mathrm{K}$ & $\mathrm{Ca}$ & $\mathrm{Fe}$ \\
\hline Sapwood 1 & 0.01 & 0.03 & - & 0.01 & 0.05 & - & - & 0.20 & 0.07 & 0.02 \\
Sapwood 2 & - & 0.03 & - & - & 0.02 & - & - & 0.18 & 0.07 & - \\
Sapwood 3 & - & 0.01 & - & - & - & - & - & 0.11 & 0.30 & - \\
Heartwood 1 & $<0.01$ & $<0.01$ & - & 0.01 & $<0.01$ & - & - & 0.07 & 0.04 & 0.01 \\
Heartwood 2 & - & 0.01 & - & - & $<0.01$ & - & - & 0.06 & 0.05 & - \\
Heartwood 3 & - & $<0.01$ & - & - & - & - & - & 0.06 & 0.20 & - \\
\hline EDXA 1 & 0.03 & 0.09 & 0.07 & 0.02 & 0.04 & 0.08 & 0.07 & 0.25 & 0.31 & 0.31 \\
EDXA 2 & 0.14 & 0.60 & 0.88 & $\mathbf{3 . 2 5}$ & 0.46 & $\mathbf{3 . 5 4}$ & 0.19 & 0.99 & $\mathbf{4 . 0 5}$ & 0.65 \\
EDXA 3 & 0.06 & 0.15 & $<0.01$ & $\mathbf{5 0 . 3 1}$ & 0.17 & 0.14 & $<0.01$ & $<0.01$ & $<0.01$ & 0.22 \\
EDXA 4 & 0.14 & 0.37 & 0.18 & 0.57 & 0.11 & 0.62 & 0.09 & 0.33 & 0.59 & $\mathbf{6 6 . 2 8}$ \\
EDXA 5 & 0.05 & 0.15 & 0.08 & 0.12 & 0.02 & 0.06 & 0.02 & 0.08 & $\mathbf{2 1 . 6 1}$ & 0.08 \\
\hline
\end{tabular}

radial alignments of chambered cells inside multiseriate rays. The prismatic crystals shown in Figure 6B are probably of two distinct types or orientations, since they have different optical properties: two crystals are clearly highlighted, while several other remain opaque. No crystals were observed in uniseriate ray cells, vessels, vasicentric tracheids or fibers. Since no longitudinal sections have been made, it could not be verified whether the crystalliferous axial parenchyma cells were chambered or not.

\section{DISCUSSION}

\subsection{Identification, localisation and possible causes of mineral deposits in sessile oak wood}

When mineral deposits are reported in literature, usually neither their chemical composition nor their abundance is specified. In the majority of cases, only the crystal shape and the number per cell are given and it is implicitly assumed that they consist of calcium oxalate or calcium carbonate because this mineral is the most common in wood and it resists to most micro-technical treatments $[4,21]$. The scanning electron and light microscopical observations and the chemical analyses that were performed convincingly proved the inorganic nature and endogenous origin of the light-saturated pixels ("C-pixels") encountered in scanned X-ray images of sessile oak wood. The occurrence of such pixels is unquestionably linked to the presence in the wood strips of mineral inclusions - amorphous or crystal-shaped - with specific densities well above that of ligneous material.

The results indicate that at least two types of crystalline compounds are present in the oak wood studied. One type is rich in silicium (EDXA 3), the other has calcium as its 


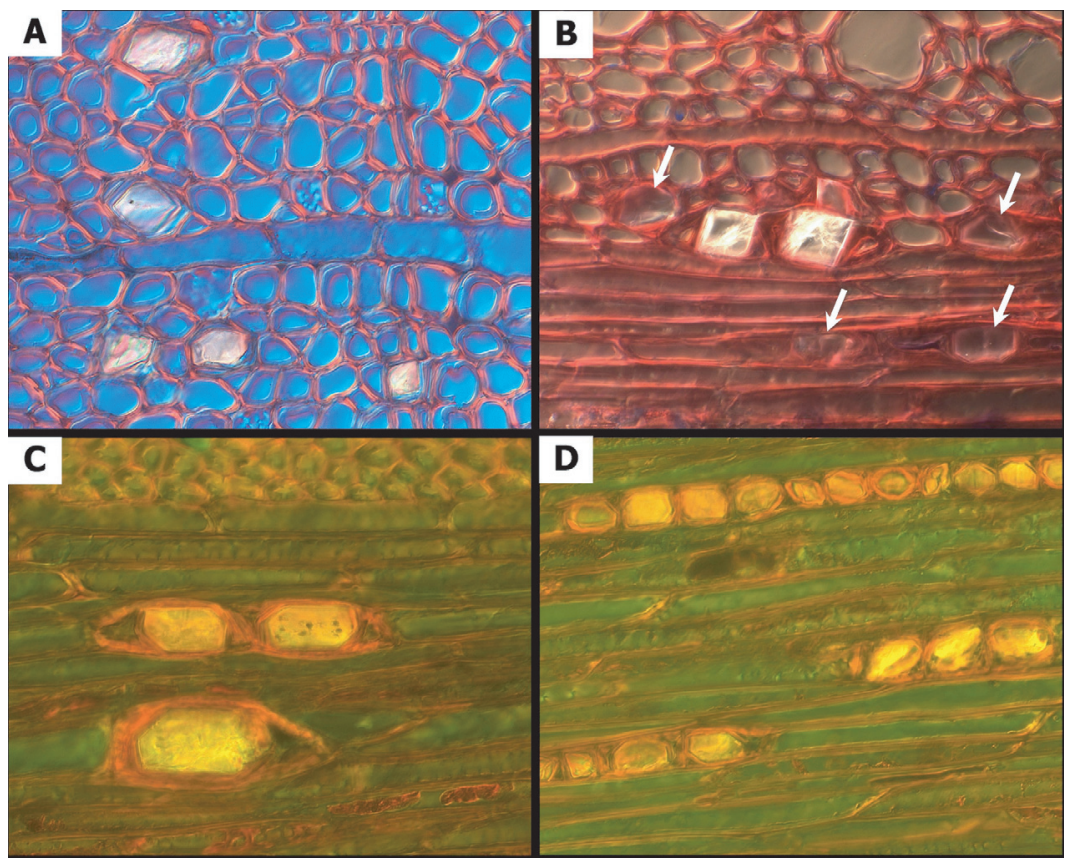

Figure 6. Prismatic crystals observed in thin cross-sections under the light microscope at $100 \times$ magnification: (A) in axial parenchyma cells, highlighted with Nomarski differential interference contrast (NDIC); (B) in cells bordering a multiseriate ray, made apparent with darkfield illumination and NDIC - some crystals remain opaque (white arrows); (C) in multiseriate ray cells, lit-up with fluorescence light and NDIC enhancement; (D) idem, radial alignments of chambered crystal-bearing cells in multiseriate wood rays. All images were taken in the latewood zone of annual rings.

main mineral component (EDXA 5, Tab. II), and they have different optical properties (cf. Fig. 6B). This suggested that the two minerals most common in wood, i.e. silica and calcium oxalate, were jointly present, which is not very common. With the exception of two sole species out of 750 investigated, Richter [21] found those minerals to be mutually exclusive in Lauraceae, a plant family counting thousands of species. Out of the 350 taxa described anatomically in the Intkeydatabase [21,22] only 30 indicate co-occurrence of crystals and silica. According to Carlquist [4] - who attributes considerable taxonomic importance to silica occurrence - detectable silica accumulations have not been reported in Fagaceae, except in Nothofagus.

Silica $\left(\mathrm{SiO}_{2}\right)$ contains $47 \%$ silicium and $53 \%$ oxygen and has a specific density of over 2.5. Calcium oxalate has a chemical formula that differs depending on the state of hydration - $\mathrm{Ca}\left(\mathrm{C}_{2} \mathrm{O}_{4}\right) \cdot \mathrm{n}\left(\mathrm{H}_{2} \mathrm{O}\right)$ with $\mathrm{n}$ varying from 1 to 3 - and $\mathrm{Ca}$ concentrations that vary accordingly, 27\%, 24\% and 22\% respectively. This results in specific densities ranging from 2.21 over 2.02 down to 1.85 . A Ca-concentration of $22 \%$ corresponds, thus, with the tri-hydrated form.

Apart from crystalloid shapes, the sessile oak wood was found to contain amorphous mineral inclusions as well (Fig. 5A). One of such granules examined was highly rich in iron (EDXA 4), possibly associated with small amounts of other elements, such as sulphur. The results of EDXA 2 indicate that objects with still other mineral compositions are present, probably salts or oxides of sodium, magnesium, aluminium, phosphorous, chlorine or potassium (Tab. II).
The image analysis of the strips of trees I and II demonstrated that the mineral inclusions reached peak concentrations at the beginning of the latewood (Figs. 1, 2 and 4) and mainly in multiseriate wood rays (Figs. 6C and 6D). Considering the particular leaf phenology of Sessile oak - budburst occurs only after the earlywood has been formed in ring-porous oaks $[2,26]$ - the accumulation of substances involved in crystal formation probably coincides with the build-up of leaf area and a concomitant increase of canopy transpiration and $\mathrm{CO}_{2}-$ assimilation in late spring and early summer. This accumulation is more important in wide rings, because of the positive relation existing between latewood width and ring width in ring-porous oaks $[25,27]$. This does not imply, however, a causal relationship between growth rate and mineral deposits, as has been suggested by Mariaux [14] for the tropical species Aucoumea klaineana Pierre, but merely an allometric one.

The variations of crystal proportion observed between subsequent rings in tree I and between sapwood and heartwood rings (Fig. 3) might be due to differences in the relative intraring concentrations of both minerals, as a result of differences in specific density between silica (2.65) and calcium oxalate (1.85). Inter-annual variations may indicate also that the processes involved in mineral accumulation are caused by yearto-year differences in climate. Moreover, the variations appear to be associated with heartwood formation, because an important increase of C-pixels has been observed at the sapwoodto-heartwood transition which is maintained in the heartwood (Fig. 3). 
Even though mineral inclusions are often treated as accidental or anomalous, their formation in trees may also result from normal physiological processes [10]. It is generally accepted $[4,8,15]$ that the formation of mineral inclusions is induced or increases when the main functions of the woody tissues shift from transport and storage of water, minerals and assimilates, as in sapwood and earlywood, to mechanical support and protection against xylophagous attacks or decay by micro-organisms, as in heartwood and latewood. The accumulation of calcite in xylem vessels of diffuse-porous Pориlus spp., observed by Janin and Clément [10], suggests that the formation of mineral deposits is preceded by the loss of sap conducting function in vessels through cavitation. Cavitation occurs naturally in xylem vessels, either as a result of extreme drought stress, frost-induced embolisms or mechanical rupture, and prior to heartwood formation [28]. Because the senescence of parenchymatous cells, which is normally also associated with heartwood formation $[8,11,13]$, can be seen both as cause and result of such functional changes, a part of the sapwood's parenchyma cells must have died prematurely in crystal bearing oaks. According to Hillis [8], silica can be found in the sapwood of a number of species long before heartwood extractives are formed, while crystals of calcium oxalate or calcium carbonate are found much more frequently in heartwood than in sapwood. This suggests a different timing of crystallization, with silica being formed some time before calcium oxalate. However, according to Meerts [15], the concentration of calcium is usually markedly lower in heartwood compared to sapwood, which would indicate a natural predominance of silica over calcium oxalate in oak heartwood. Bigger relative proportions of higher density silica could result in an overall higher detection of C-pixels in heartwood rings in X-rays. As such, the variable amount of mineral deposits observed between years - already noticeable in the sapwood rings - may also be caused by variations in the relative proportions of both minerals. More likely, however, inter-annual variations may be explained by climate dependent influences, not only those ruling in the year a growth ring was formed but also those governing the year(s) during which a ring was transformed into heartwood. In the majority of the storage cells, nevertheless, crystal deposition seems to take place weeks, months or years after the accumulation of mineral precursors occurred. A delayed deposition of calcium carbonate crystals had been observed also in Populus by Janin and Clément [10], resulting in higher crystal accumulations in heartwood compared to sapwood rings. It is difficult to assess whether mineral precursors are continuously accumulated and immobilized inside storage cells in sessile oak, year after year until they crystallize, or if the accumulation derives from radial and longitudinal translocation of mineral precursors during a shorter period that is onset when cell death is imminent. It remains to be investigated, moreover, whether the formation and deposition of inorganic material occurs in parallel with or independent from that of organic extractives, because investigations of heartwood formation usually focus on qualitative and quantitative changes concerning primarily carbohydrates and phenolics $[11,13]$. The majority of the mineral deposits seem to be formed in situ in the sapwood-heartwood transition zone to- gether with heartwood phenolics, possibly through chemical processes that are characteristic of the Type 1 or Robinia-Type of heartwood formation, as described by Magel [13]. However, in the oaks studied, crystals occurred also in sapwood rings. Thus, the normal pattern of element resorption observed in Quercus sp. near the sapwood-heartwood boundary [18] has been disturbed in the crystal-bearing oaks under study. In their investigations on poplar trees, which form false heartwood, Janin and Clément [10] raised the concept of a hinge-ring that acts as a barrier between sapwood and heartwood rings: on the sapwood side and especially near the cambial zone, resorption of the cations $\mathrm{Ca}^{++}, \mathrm{Mg}^{++}$and $\mathrm{K}^{+}$occurs and on the heartwood side these cations are being accumulated and immobilized. These processes are associated with a nearly complete depletion of phosphorous - an important element in the living tree biochemistry - in the hinge-ring and in rings on the heartwood side. Crystal deposition in sessile oaks, which form true heartwood, seems to result from a complex interaction of natural processes including ecophysiological reactions to hydraulic dysfunction as well as biochemical adaptations associated with normal cambial activity and heartwood formation. In ring-porous oaks, the position of the hinge-ring must be located closer to the cambium than in diffuse-porous species like poplars.

The radial position of the central sapwood-to-heartwood transition ring, i.e. its absolute distance or age counted from the cambium, and the abundance of mineral inclusions differ considerably between trees, notably between trees I and II. Radial variations of the elementary mineral content found in oak wood have been attributed to differences in soil chemistry [18] and to soil acidification by atmospheric pollution [12]. Differences in soil nutrient factors appeared to play a major role in explaining the autecology of $Q$. petraea in northern France [1]. On the other hand, enhanced accumulation of minerals might also have been caused by unknown genotypical factors (provenance). Janin and Clément [10] showed a strong phylogenetic predisposition for calcite deposition in Populus, which was later confirmed in a study covering 28 different poplar species [5]. They consistently observed mineral streaks in species and hybrids of the sections Aigeiros, Leucoides and Tacamahaca but none in poplars of the section Leuce. Crystals generally have lower diagnostic value in European woods when compared to tropical woods [23], but the occurrence of crystalliferous wood cells is a feature that may allow discriminating Quercus spp. also. According to Jacquiot et al. [9], crystals are absent or occasionally present in $Q$. robur, $Q$. petrae $a$ and $Q$. rubra, present quite frequently in $Q$. ilex and very frequently in $Q$. cerris, $Q$. suber and $Q$. pubescens. With the methods described in this paper, mineral deposits were found either to be completely absent (or not detectable) or to be present occasionally (tree IV) up to very abundantly (tree I) in sessile oak. Even though the chemical analyses were not exhaustive, the results are considered to be valid also for stemwood of other crystal-bearing trees (II and IV) and for other positions. As only mature stemwood has been investigated, it remains to be investigated if the nature and origin of mineral inclusions in bark, roots and juvenile wood are similar. Janin and Clément [10] found that if crystals are present in the stem 
xylem of Populus, crystals can be found also in branches and roots. Trockenbrodt [24] demonstrated calcium oxalate crystals, sclereids and druses in stem bark of Quercus robur L.

\subsection{Consequences of mineral deposits for image analysis, microdensitometry and wood utilisation}

From a technical point of view, it should be noted that oak wood bearing large amounts of crystals will become more difficult to process. Silica may increase wear of woodworking tools [5], enhance surface irregularities during sample preparation by sawing procedures [25] and - in wood dust - may be irritating to the respiratory system [8].

The total X-ray attenuation in a unit volume of air-dried wood - captured on radiographic film and translated into one of 256 grey-values - is an integrated value resulting from the attenuation of X-rays by porous ligneous material (cell walls including about $12 \%$ moisture and air-filled spaces) and, facultatively, by that of inorganic matter. In the image analysis of X-ray photos, the presence of high-density mineral inclusions will affect the density values of tissues that are contaminated and the surface proportions of vasicentric tracheids, fibers and multiseriate rays will be underestimated (as shown in the rings shown in Fig. 2). Considering that the mineral inclusions have been found mainly in the latewood zones of oak growth rings (Figs. 1, 2 and 4) and that they cause local greyvalue saturation, hence density value inflation, detection of the earlywood-latewood transition based on the intersection of the radial microdensity profile with a threshold of density derived from minimum and maximum ring densities, as proposed by Mothe et al. [16], should be facilitated in oak wood bearing substantial amounts of crystals. Moreover, as had been shown already by Clément and Janin [5], the predominant occurrence of mineral inclusions in heartwood offers an objective standard to discriminate sapwood from heartwood rings, even in species with indistinct or false heartwood, on account of their appearance as (nearly) light-saturated pixels in radiographic images (negatives).

The additive effect on wood density caused by the presence of mineral inclusions is difficult to estimate for several reasons. Firstly, the attenuation coefficients of minerals containing $\mathrm{Ca}$ (e.g. calcium oxalate and carbonate) and $\mathrm{Si}$ (e.g. silica) are much higher than those of wood polymers consisting primarily of $\mathrm{C}, \mathrm{H}$ and $\mathrm{O}$. Furthermore, apart from X-ray attenuation through photoelectric absorption and Compton scattering, crystal structures induce increased diffraction $[3,19,20]$. Secondly, since no information is available on their longitudinal distribution - throughout the thickness of the irradiated sample - and knowing that the inorganic mass typically amounts to maximum $1.0 \%$ in woods from temperate zones [8], the estimated surface proportion of crystals (Tab. I) is most likely not a reliable measure of the volumetric proportion. Thirdly, intra-ring density variations do not solely depend on the ratio of ligneous to inorganic matter, but also on genetics, cambial age, anatomical composition, heartwood formation, ring width and intra-ring position $[6,16,19,20,25,27]$.
In spite of uncertainties concerning the previously mentioned factors, the grey-level saturation observed in the X-ray negatives indicates that a proportional increase of wood density is to be expected, locally, when accessory substances with densities of more than $1.53 \mathrm{~g} / \mathrm{cm}^{3}$ are present in substantial amounts. For instance, adding $7.5 \%$ tri-hydrated calcium oxalate of density $1.85 \mathrm{~g} / \mathrm{cm}^{3}$ to woody tissue which normally has a volumetric weight of $0.600 \mathrm{~g} / \mathrm{cm}^{3}$ should theoretically result in a $0.094 \mathrm{~g} / \mathrm{cm}^{3}$ or nearly $16 \%$ density increase; $7.5 \%$ silica of density $2.65 \mathrm{~g} / \mathrm{cm}^{3}$ will produce a $0.154 \mathrm{~g} / \mathrm{cm}^{3}$ or over $25 \%$ increase. The higher average ring density recorded in heartwood $\left(0.761 \mathrm{~g} / \mathrm{cm}^{3}, 12.9 \%\right.$ C-pixels $)$ compared to sap$\operatorname{wood}\left(0.582 \mathrm{~g} / \mathrm{cm}^{3}, 4.2 \%\right.$ C-pixels $)$ in tree I, demonstrates this effect [25].

Acknowledgements: The results presented in this paper have been obtained in the framework of a doctoral thesis performed at the Équipe de Recherches sur la Qualité des Bois of the Laboratoire d'Étude des Ressources Forêt-Bois (LERFOB, INRA-ENGREF Nancy) [25]. This work has been financed by the EU-FAIR programme "Training and Mobility of Researchers", contract No. FAIRBM-974111, entitled "Fast quantitative assessment of the anatomical structure of oak wood through automated analysis of radiographical images".

\section{REFERENCES}

[1] Bergès L., Chevalier R., Dumas Y., Franc A., Gilbert J.-M., Sessile oak (Quercus petraea Liebl.) site index variations in relation to climate, topography and soil in even-aged high-forest stands in northern France, Ann. For. Sci. 62 (2005) 391-402.

[2] Breda N., Granier A., Intra- and interannual variations of transpiration, leaf area index and radial growth of a sessile oak stand (Quercus petraea), Ann. Sci. For. 53 (1996) 521-536.

[3] Bucur V., Nondestructive characterization and imaging of wood, Springer Verlag, Berlin, Heidelberg, New York, 2003, 354 p.

[4] Carlquist S., Comparative wood anatomy, Systematical, ecological and evolutionary aspects of Dicotyledon wood, Springer Verlag, Berlin, Heidelberg, New York, 1988, 436 p.

[5] Clément A., Janin G., Étude complémentaire de la présence de cristaux de carbonate de calcium dans le bois de peupliers. Existence de cinq zones fonctionnelles reconnues à partir de leurs teneurs en phosphore, Ann. Sci. For. 30 (1973) 63-81.

[6] Guilley E., Mothe F., Nepveu G., A procedure based on conditional probabilities to estimate proportions and densities of tissues from X-ray images of Quercus petraea samples, IAWA J. 23 (2002) 235252.

[7] Hägglund E, Chemistry of wood, Academic Press Inc., New York, $1951,631 \mathrm{p}$.

[8] Hillis W.E., Heartwood and tree exudates, Springer Verlag, Berlin, Heidelberg, New York, 1987, 268 p.

[9] Jacquiot C., Trénard Y., Dirol D., Atlas d'anatomie des bois des Angiospermes (essences feuillues), Tome 1 - texte, CTB, Paris, 1973, pp. 116-119.

[10] Janin G., Clément A., Mise en évidence de cristaux de carbonate de calcium dans le bois des peupliers. Conséquences sur la répartition des ions minéraux liée à la duraminisation, Ann. Sci. For. 29 (1972) 67-105.

[11] Label P., Beritognolo I., Burtin P., Dehon L., Couée I., Breton C., Charpentier J.-P., Jay-Allemand C., Cambial activity and xylem differentiation in walnut (Juglans sp.), in: Savidge R.A., Barnett J.R., 
Napier R. (Eds.), Cell and molecular biology of wood formation, BIOS Scientific Publishers Ltd., Oxford, 2000, pp. 209-221.

[12] Lévy G., Bréchet C., Becker M., Element analysis of tree rings in pedunculate oak heartwood: an indicator of historical trends in the soil chemistry, related to atmospheric deposition, Ann. Sci. For. 53 (1996) 685-696.

[13] Magel E.A., Biochemistry and physiology of heartwood formation, in: Savidge R.A., Barnett J.R., Napier R. (Eds.), Cell and molecular biology of wood formation, BIOS Scientific Publishers Ltd., Oxford, 2000, pp. 363-386.

[14] Mariaux A., Formation of silica grains in wood as a function of growth rate, IAWA Bull. n.s. 1 (3), 1980, 140-142.

[15] Meerts P., Mineral nutrient concentrations in sapwood and heartwood: a literature review, Ann. For. Sci. 59 (2002) 713-722.

[16] Mothe F., Sciama D., Leban J.M., Nepveu G., Localisation de la transition bois initial - bois final dans un cerne de Chêne par analyse microdensitométrique, Ann. Sci. For. 55 (1998) 437-449.

[17] Nepveu G., Keller R., Teissier Du Cros E., Sélection juvénile pour la qualité du bois chez certains peupliers noirs, Ann. Sci. For. 35 (1978) 69-92.

[18] Penninckx V., Glineur S., Gruber W., Herbauts J., Meerts P., Radial variations in wood mineral element concentrations: a comparison of beech and pedunculate oak from the Belgian Ardennes, Ann. For. Sci. 58 (2001) 253-260.

[19] Polge H., Établissement des courbes de variation de la densité du bois par exploration densitométrique de radiographies d'échantillons prélevés à la tarière sur des arbres vivants. I. Applications dans les domaines technologique et physiologique, Ann. Sci. For. 23 (1966) 1-187.

[20] Polge H., Établissement des courbes de variation de la densité du bois par exploration densitométrique de radiographies d'échantillons prélevés à la tarière sur des arbres vivants. II.
Utilisation des spectres de diffraction des rayons X pour les études de qualité du bois, Ph.D. thesis in Applied Sciences, Université de Nancy, France, 1966, 215 p.

[21] Richter H.G., Occurrence, morphology and taxonomic implications of crystalline and siliceous inclusions in the secondary xylem of the Lauraceae and related families, Wood Sci. Technol. 14 (1980) $35-44$.

[22] Richter H.G., Dallwitz M.J., Commercial timbers: descriptions, illustrations, identification, and information retrieval, in English, French, German and Spanish (2000 onwards), http://deltaintkey.com/wood/index.htm.

[23] Schweingruber F.H., Anatomie europäischer Hölzer: ein Atlas zur Bestimmung europäischer Baum-, Strauch- und Zwergstrauchölzer, Stuttgart: Haupt, 1990, p. 53.

[24] Trockenbrodt M., Calcium-oxalate crystals in the bark of Quercus robur, Ulmus glabra, Populus tremula and Betula pendula, Ann. Bot. 75 (1995) 281-284.

[25] Vansteenkiste D., Mise au point et application d'une méthode rapide d'analyse quantitative de l'anatomie du bois de chêne: analyse d'image automatisée de clichés radiographiques de barrettes transversales de bois de faible épaisseur, Ph.D. thesis in Forestry and Wood Sciences, INRA-ENGREF Nancy, France, 2002, 403 p.

[26] Zasada J.C., Zahner R., Vessel element development in the earlywood of red oak (Quercus rubra), Can. J. Bot. 47 (1969) 19651971.

[27] Zhang S.Y., Variations and correlations of various ring width and ring density features in European oak: implications in dendroclimatology, Wood Sci. Technol. 31 (1997) 63-72.

[28] Zimmermann M.H., Xylem structure and the ascent of sap, Springer Verlag, Berlin, Heidelberg, New York, 1983, 143 p. 